\title{
PENGARUH JALAN CEPAT (BRISK WALKING) TERHADAP PENURUNAN GLUKOSA DARAH PADA PASIEN DIABETES MELLITUS TIPE II YANG BEROBAT JALAN DI RUMAH SAKIT UMUM IMELDA PEKERJA INDONESIA MEDAN
}

\author{
${ }^{1}$ Hamonangan Damanik, ${ }^{2}$ Paskah Rina Situmorang \\ ${ }^{1,2}$ Dosen Prodi S-1Keperawatan, STIKes Imelda, Jalan Bilal Nomor 52 Medan \\ E-mail: ${ }^{1}$ hamonangan1112@gmail.com, ${ }^{2}$ paskahsitumorang85@gmail.com
}

\begin{abstract}
ABSTRAK
Diabetes Mellitus (DM) merupakan suatu penyakit menahun yang ditandai oleh kadar kadar glukosa darah melebihi normal dan gangguan metabolisme karbohidrat, lemak dan protein yang disebabkan oleh kekurangan hormon insulin secara relatif maupun absolut. Penelitian ini bertujuan untuk mengetahui pengaruh jalan cepat terhadap penurunan gula darah pada pasien DM tipe 2 yang berobat jalan di Rumah Sakit Umum Imelda Pekerja Indonesia (RSU IPI) Medan. Jenis penelitian ini menggunakan quasi experiment dengan desain penelitian "one group pretest and posttest". Penelitian ini dilakukan pada pasien diabetes melitus tipe II yang berobat jalan di Rumah Sakit Umum Imelda Pekerja Indonesia (RSU IPI) Medan. Populasi pada penelitian ini adalah 109 orang. Tehnik sampling pada penelitian ini adalah accidental sampling (responden yang tersedia sewaktu dilakukan penelitian) dengan demikian jumlah sampel adalah 19 orang. Analisis statistik yang digunakan uji wilcoxon test. Setelah sampel ditentukan, maka peneliti akan melakukan penelitian dari rumah ke rumah pasien. Proses penelitian dilakukan yaitu dengan melakukan tes gula darah kemudian melakukan jalan cepat bersama pasien selama 30 menit kemudian dilakukan pengecekan kembali gula darah. Hasil penelitian menunjukkan bahwa mayoritas pendetita DM mengalami penurunan kadar gula darah. Hasil analisis data menggunakan wilcoxon test diperoleh nilai p hitung 0,002 < 0,05. Disarankan kepada responden agar tetap menjaga kadar gula darah dengan melakukan latihan jasmani seperti jalan cepat.
\end{abstract}

Kata kunci: diabetes mellitus, jalan cepat, gula darah.

\begin{abstract}
Diabetes Mellitus (DM) is a chronic disease characterized by excessive levels of protein and fats that contain protein, fat and protein caused by a deficiency of the hormone insulin. This study discusses how to improve DM in type 2 DM patients who seek treatment at the Indonesian Workers General Hospital (IPI Hospital) Medan. This type of research uses quasi-experimental research design "one group pretest and posttest". This study was conducted on type II diabetes mellitus patients who were treated at the Indonesian Workers' Hospital (IPI Hospital) Medan. The population in this study was 109 people. The research sample in this study was accidental sampling (respondents were available at the time of the study) so the number of samples was 19 people. Statistical analysis used Wilcoxon test. After the sample is determined, then the researcher will conduct research from house to house of the patient. The research process is carried out by carrying out a blood test then doing a brisk walk with the patient for 30 minutes and then checking the blood sugar again. The results of research that prove the distribution of DM The results of data analysis using the Wilcoxon test obtained p value of $0.002<0.05$. Published to respondents to keep blood sugar levels with physical exercise such as brisk walking.
\end{abstract}

Keywords: Diabetes Mellitus, Brisk Walking, Blood Sugar.

\section{PENDAHULUAN}

Diabetes Mellitus (DM) merupakan suatu penyakit menahun yang ditandai oleh kadar glukosa darah melebihi normal dan gangguan metabolisme karbohidrat, lemak dan protein yang disebabkan oleh kekurangan hormon insulin secara relatif maupun absolut. Bila hal ini dibiarkan tidak terkendali dapat terjadi komplikasi metabolik akut maupun komplikasi vaskuler jangka panjang, baik mikroangiopati maupun makroangiopati (Darmono, 2010). 
World Health Organization (WHO) memprediksi adanya peningkatan jumlah penderita DM yang cukup besar dari 415 juta jiwa pada tahun 2015 menjadi sekitar 642 juta jiwa pada tahun 2040. Pada tahun 2014 terdapat 96 juta orang dewasa dengan DM di sebelas negara anggota diwilayah regional Asia Tenggara. Populasi dari wilayah regional di Asia Tenggara secara genetik memang rentan terhadap faktor diabetogenik lingkungan, sehingga memiliki ambang lebih rendah terhadap faktor resiko seperti usia, kelebihan berat badan dan distribusi lemak tubuh (Riskesdas, 2018).

Penderita DM di Sumatera Utara juga meningkat setiap tahunnya. Pada tahun 2013, Sumatera Utara memiliki prevalensi DM sebesar 5,3\% atau hanya $0,4 \%$ di bawah rata-rata nasional. Meskipun demikian, prevalensi ini harus diwaspadai karena penderita yang telah mengetahui memiliki DM sebelumnya hanya sebesar $26 \%$, sedangkan sekitar $74 \%$ yang tidak mengetahui bahwa mereka telah menderita DM (Lindarto, 2013). Menurut (Riskesdas, 2013) prevalensi DM di Sumatera Utara berdasarkan wawancara terdiagnosis dokter atau gejala adalah sebesar 2,3\%, jumlah ini meningkat dari survei tahun 2007 sebesar 1,21\% (Riskesdas, 2013).

Dalam (Perkeni, 2015) disebutkan bahwa olahraga secara teratur dapat memperbaiki kendali glukosa darah, mempertahankan atau menurunkan berat badan, serta dapat meningkatkan kadar kolesterol HDL. Pada kedua tipe DM, dengan melakukan latihan jasmani atau olahraga terbukti dapat meningkatkan pemakaian glukosa oleh sel sehingga KGD turun (Corwin, 2010).

Jalan cepat merupakan salah satu olahraga aerobik yang dapat menjaga KGD dalam rentang normal. Selain bermanfaat untuk menjaga KGD olahraga yang bersifat aerobik juga dapat bermanfaat untuk menurunkan resiko komplikasi DM tipe 2, penyakit jantung dan stroke (Darwin \& Reni, 2013).

Berdasarkan hasil penelitian (Putri, 2016) menemukan bahwa latihan jasmani yang dilaksanakan sebanyak 3 kali 30 menit per minggu dapat mengurangi risiko pada penderita DM tipe 2 untuk mempunyai KGD tidak terkontrol. Hasil penelitian (Listyarini dan Fadilah, 2017) ada pengaruh jalan cepat (brisk walking) terhadap penurunan KGD penderita DM tipe 2 di Desa Klumpit Kecamatan Gebog Kabupaten Kudus. Sejalan dengan penelitian (Fauzi, 2013) menyatakan bahwa ada perbedaan antara jalan kaki dengan intensitas sedang dan tinggi terhadap penurunan KGD pada pasien DM tipe 2 ringan

\section{Kerangka Pikir}

Adapun kerangka pemikiran untuk penelitian ini adalah sebagai berikut:

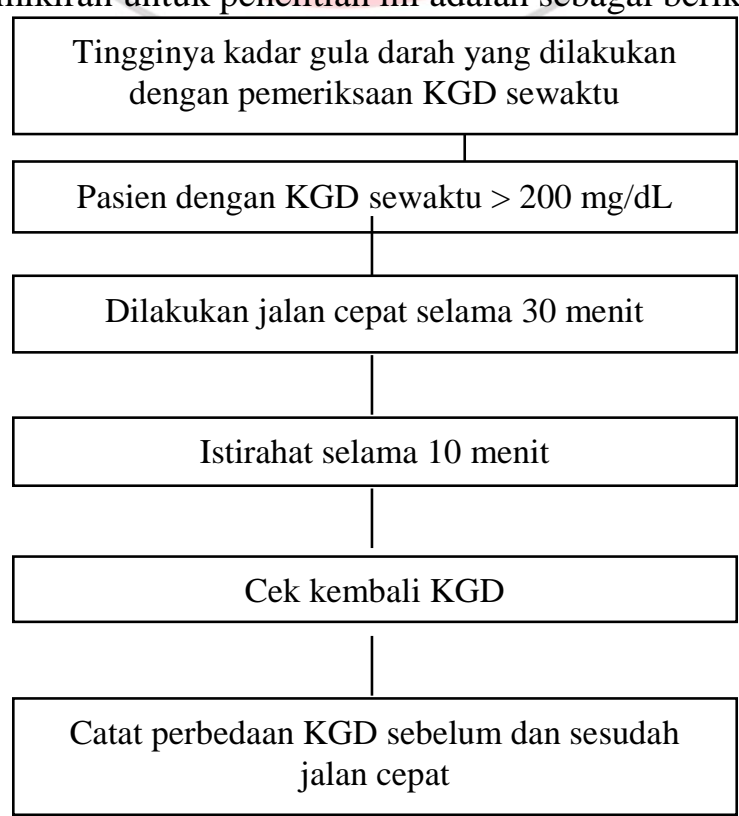




\section{METODE PENELITIAN}

Jenis penelitian ini menggunakan metode pre experimen dengan desain penelitian "one group pretest-posttest". Penelitian ini dilakukan pada pasien diabetes melitus tipe II dengan KGD sewaktu > 200 $\mathrm{mg} / \mathrm{dL}$ yang berobat jalan di Rumah Sakit Umum Imelda Pekerja Indonesia (RSU IPI) Medan. Penelitian dilakukan pada bulan Maret 2019 di Rumah Sakit Umum Imelda Pekerja Indonesia (RSU IPI) Medan. Populasi dalam penelitian ini adalah seluruh pasien rawat jalan yang mengalami DM tipe 2 dengan KGD sewaktu $>200 \mathrm{mg} / \mathrm{dL}$. Tehnik sampling pada penelitian ini adalah purposive sampling.

Kriteria inklusi yaitu: (1) pasien dengan DM tipe 2; (2) KGD sewaktu > $200 \mathrm{mg} / \mathrm{dL}$; (3) bersedia menjadi responden; (4) tidak mengalami gangguan pada kaki/lumpuh, sedangkan kriteria eksklusi yaitu: (1) tidak bersedia menjadi responden; (2) tidak bersedia mengikuti jalan cepat. Dengan demikian jumlah sampel pada penelitian ini sebanyak 19 orang.

\section{HASIL}

Berdasarkan penelitian, nilai kadar gula darah penderita DM sebelum jalan cepat dapat dilihat pada tabel dibawah ini.

Tabel 1. Distribusi Frekuensi KGD Sebelum Jalan Cepat

\begin{tabular}{|c|c|c|c|c|c|c|c|c|}
\hline \multirow[t]{2}{*}{ No } & \multicolumn{8}{|c|}{ KGD Sebelum Jalan Cepat } \\
\hline & $\begin{array}{c}\text { hari ke } \\
1\end{array}$ & hari ke 2 & hari ke 3 & hari ke 4 & hari ke 5 & hari ke 6 & $\begin{array}{c}\text { hari ke } \\
7\end{array}$ & $\begin{array}{l}\text { rata- } \\
\text { rata }\end{array}$ \\
\hline 1 & 223 & 222 & 223 & 223 & 224 & 222 & 222 & 222,71 \\
\hline 2 & 230 & 230 & 231 & 231 & 230 & 230 & 231 & 230,43 \\
\hline 3 & 208 & 208 & 209 & 208 & 209 & 207 & 207 & 208 \\
\hline 4 & 211 & 210 & 211 & 211 & 210 & 210 & 210 & 210,43 \\
\hline 5 & 216 & 215 & 216 & 213 & 213 & 212 & 212 & 213,86 \\
\hline 6 & 225 & 220 & 220 & 219 & 219 & 218 & 218 & 219,86 \\
\hline 7 & 234 & 234 & 235 & 234 & 232 & 231 & 231 & 233 \\
\hline 8 & 229 & 229 & 228 & 228 & 227 & 226 & 226 & 227,57 \\
\hline 9 & 215 & 215 & 215 & 214 & 213 & 214 & 213 & 214,14 \\
\hline 10 & 235 & 233 & 234 & 234 & 232 & 232 & 231 & 233 \\
\hline 11 & 208 & 210 & 213 & 209 & 208 & 210 & 210 & 209,71 \\
\hline 12 & 253 & 253 & 255 & 254 & 254 & 253 & 253 & 253,57 \\
\hline 13 & 243 & 243 & 243 & 231 & 241 & 240 & 240 & 240,14 \\
\hline 14 & 200 & 201 & 203 & 203 & 201 & 201 & 201 & 201,43 \\
\hline 15 & 239 & 236 & 237 & 237 & 234 & 233 & 233 & 235,57 \\
\hline 16 & 218 & 218 & 215 & 216 & 215 & 214 & 214 & 215,71 \\
\hline 17 & 229 & 227 & 227 & 225 & 225 & 223 & 220 & 225,14 \\
\hline 18 & 258 & 256 & 250 & 251 & 249 & 247 & 247 & 251,14 \\
\hline
\end{tabular}

1. Mengukur kadar gula darah pasien dengan KGD sewaktu $>200 \mathrm{mg} / \mathrm{dL}$.

2. Melakukan kontrak dengan pasien untuk mengikuti jalan cepat serta menginformasikan kepada pasien untuk berpakaian olahraga, membawa handuk kecil dan air minum.

3. Mengajarkan dan melakukan jalan cepat bersama pasien selama 30 menit.

4. Beristirahat selama 10 menit.

5. Mengukur kembali kadar gula darah.

6. Mencatat perbedaan kadar gula darah sebelum dan sesudah jalan cepat.

Untuk membuktikan adanya pengaruh yang signifikan antara variabel digunakan analisis Wilcoxon Test, pada batas kemaknaan perhiungan statistic $\mathrm{P}$ value $(0,05)$. Apabila hasil perhitungan menunjukkan nilai $\mathrm{P}<\mathrm{P}$ value $(0,05)$ maka dikatakan (Ho) ditolak dan (Ha) diterima, artinya kedua varaiabel secara statistic mempunyai pengaruh yang signifikan. sebagai berikut: 


\begin{tabular}{lllllllll}
\hline 19 & 244 & 244 & 241 & 241 & 241 & 240 & 240 & 241,57 \\
\hline
\end{tabular}

Tabel 2. Distribusi Frekuensi KGD Sesudah Jalan Cepat

\begin{tabular}{ccccccccc}
\hline No & \multicolumn{7}{c}{ KGD sesudah jalan cepat } \\
\hline 1 & 220 & 219 & 219 & 219 & 220 & 219 & 219 & 219,29 \\
\hline 2 & 226 & 226 & 225 & 225 & 227 & 227 & 226 & 226 \\
\hline 3 & 205 & 205 & 204 & 204 & 203 & 204 & 203 & 204 \\
\hline 4 & 207 & 207 & 207 & 206 & 206 & 206 & 206 & 206,43 \\
\hline 5 & 211 & 211 & 210 & 210 & 210 & 209 & 209 & 210 \\
\hline 6 & 220 & 220 & 218 & 217 & 215 & 215 & 215 & 217,14 \\
\hline 7 & 230 & 230 & 230 & 229 & 229 & 228 & 227 & 261,86 \\
\hline 8 & 225 & 220 & 221 & 220 & 221 & 220 & 220 & 221 \\
\hline 9 & 210 & 210 & 211 & 210 & 210 & 210 & 209 & 210 \\
\hline 10 & 230 & 230 & 229 & 230 & 229 & 228 & 228 & 229,14 \\
\hline 11 & 206 & 206 & 207 & 206 & 207 & 207 & 207 & 206,57 \\
\hline 12 & 250 & 250 & 250 & 248 & 248 & 247 & 247 & 248,57 \\
\hline 13 & 240 & 240 & 240 & 231 & 235 & 235 & 235 & 236,57 \\
\hline 14 & 198 & 198 & 197 & 198 & 197 & 197 & 197 & 197,43 \\
\hline 15 & 236 & 230 & 230 & 231 & 230 & 231 & 230 & 231,14 \\
\hline 16 & 211 & 210 & 210 & 210 & 209 & 210 & 210 & 210 \\
\hline 17 & 221 & 222 & 223 & 219 & 219 & 219 & 217 & 220 \\
\hline 18 & 251 & 249 & 244 & 245 & 240 & 240 & 241 & 244,29 \\
\hline 19 & 240 & 238 & 238 & 237 & 238 & 237 & 237 & 237,86 \\
\hline & & & & & & & & \\
\hline
\end{tabular}

Berdasarkan tabel diatas, diketahui bahwa mayoritas pendetita DM mengalami penurunan kadar gula darah. Hasil analisis data menggunakan wilcoxon test diperoleh nilai $\mathrm{p}$ hitung $0,002<0,05$.

Tabel 3. Hasil Analisa Data Wilcoxon Test

\begin{tabular}{lllll}
\hline & Mean & $\mathrm{N}$ & Std. Deviation & sesudah - sebelum \\
\hline Sebelum & 225,63 & 19 & 14,761 & $-3,060^{\mathrm{b}}$ \\
\hline Sesudah & 223,02 & 19 & 17,099 &, 002 \\
\hline
\end{tabular}

\section{KESIMPULAN}

Dari hasil penelitian terhadap 19 orang berdasarkan hasil analisis data dan disimpulkan bahwa:

1. Hasil penelitian menunjukkan bahwa sesudah melakukan jalan cepat kadar glukosa darah penderita diabetes mellitus mampu turun rata-rata dari $225,63 \mathrm{mg} / \mathrm{dl}$ menjadi 223,02 mg/dl. Dalam hasil ini terdapat penurunan kadar glukosa darah rata-rata sebesar $2,63 \mathrm{mg} / \mathrm{dl}$.

2. Meski sebagian kecil ada yang mengalami peningkatan kadar glukosa darah akan tetapi dari hasil analisa menunjukkan bahwa ada pengaruh melakukan jalan cepat terhadap penurunan kadar glukosa darah pada penderita diabetes mellitus. Dimana dapat diperhatikan dari uji statistik wilcoxon yang menunjukkan nilai signifikansi $(\mathrm{p}=0,002)$.

\section{SARAN}

Berdasarkan hasil penelitian ini, maka saran yang dapat penulis sampaikan adalah sebagai berikut :

1. Bagi Peneliti Selanjutnya

Penelitian ini hendaknya berguna untuk peneliti selanjutnya, dan disarankan menjadi referensi penelitian yang sama dengan jumlah sampel yang lebih besar dan di tempat yang berbeda.

2. Bagi Institusi Pendidikan

Sebagai referensi perpustakan STIKes Imelda dan sebagai masukan khususnya yang berkaitan dengan penatalaksanaan DM tipe 2

3. Bagi Responden 
Disarankan kepada responden agar tetap menjaga kadar gula darah dengan melakukan latihan jasmani seperti jalan cepat.

4. Bagi Rumah Sakit

Agar dapat menerapkan terapi komplementer seperti jalan cepat untuk dapat membantu proses penyembuhan pasien khususnya jalan cepat.

\section{DAFTAR PUSTAKA}

Corwin, E. J. (2010). Buku Saku Patofisiologi Corwin. Jakarta: EGC.

Darmono. (2010). Olahraga bagi Penderita Diabetes. Semarang: Dexa Media.

Darwin, K. Reni, Z. (2013). Tingkat Pengetahuan Dan Sikap Pasien Diabetes Melitus Tentang Pencegahan Komplikasi Renitopatidi RSUD Selasih Kabupaten Pelalawan Tahun 2013.

Fauzi, L. (2013). Intensitas Jalan Kaki Terhadap Penurunan Kadar Glukosa
Darah. Jurnal Kesehatan Masyrakat. Akses online 2 maret 2019.

Lindarto. (2013). Penderita Diabetes Di Sumut Terus Meningkat. Akses Online 12 Maret 2019. URL: http://www.harianorbit.com.

Listyarini, A.D. \& Fadilah A. (2017). Brisk Walking Dapat Menurunkan Kadar Glukosa Darah Pada Penderita Diabetes Mellitus Di Desa Klumpit Kecamatan Gebog Kabupaten Kudus. Jurnal STIKes Cendekia Utama Kudus.

Putri, N. H. (2016). Hubungan Empat Pilar Pengendalian Dm Tipe 2 Dengan Rerata Kadar Gula Darah. Surabaya: Universitas airlangga.

Riskesdas. (2013). Direktorat kesehatan keluarga. Akses Online 12 maret 2019. URL : www.kememkes.go.id.

Riskesdas. (2018). Diabetes. Akses online 1 Maret 2019. URL: www.who.int.

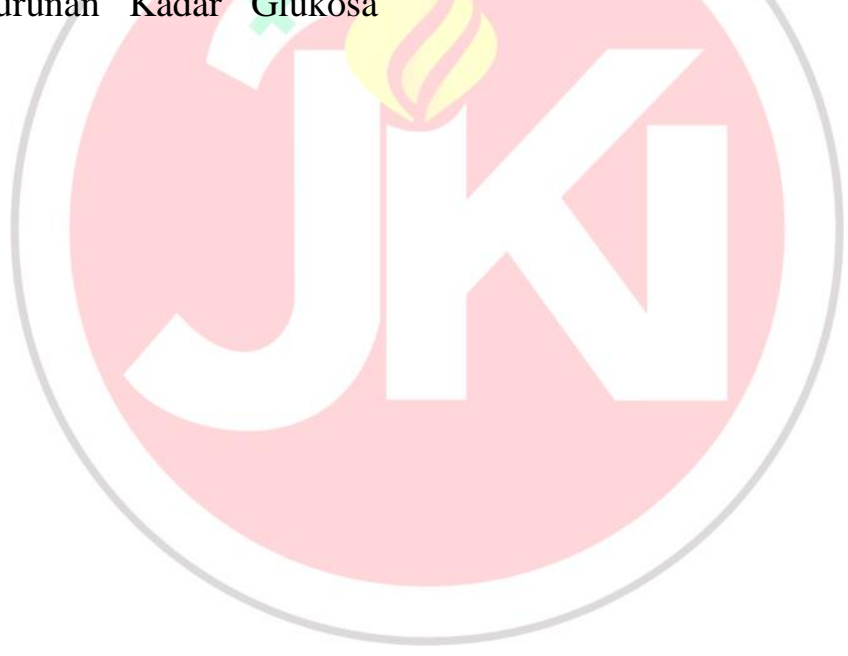

